\title{
WOORDVERWISSELING IN HET GALELAREESCH
}

\author{
DOOR
}

H. K E R N.

Naar aanleiding van de in deze Bijdragen verschenen Opmerkingen over ' $t$ Galelareesch heb ik van den zendeling van Baarda twee uitvoerige brieven ontvangen, die deels anvullingen en verbeteringen, deels nadere verklaringen en verdediging van zijne zienswijze behelzen. In die brieven komt veel voor dat van meer algemeen belang is en ik stel mij voor daarvan 't een en ander in dit tijdschrift bekend te maken. Thans wil ik uit van Baarda's schrijven slechts mededeelen wat mij 't allerbelangrijkste toeschijnt, namelijk het bij de Galelareezen heerschende gebruik om in bepaalde gevallen 't gewone woord door een ander te vervangen, hetgeen bij hen saäli genoemd wordt. Ik zal beginnen met hier te laten volgen wat van Baarda schrijft, om later over de wedergade van dat Galelareesch gebruik in andere Maleisch-Polynesische talen enkele opmerkingen te maken.

"Saäli 1 wil zeggen: een ander woord gebruiken dan het gewone, gebruikelijke, - en wel om daardoor te vermijden het noemen van de namen der oudere leden van de familie waarin men is aangetrouwd, - en van elk woord dat met die namen een zelfden uitgang of klank heeft. Dit gebruik beperkt zich niet tot Galela, maar wordt ook in andere distrikten (Tobèlo, Iolòda), wellicht in alle distrikten van Noord-Halmahera aangetroffen. - De Ternatanen houden zich daaraan niet, zoo min als de Tidoreezen, misschien is het onder hen in onbruik geraakt."

"Voor eenige woorden bezit de Galelareesche taal dubbelgangers, die het saäli gemakkelijk maken, bv. bàba en èma: vader; awa

1 Van den stam die in 't Javaansch alih luidt, en in tal van verwante talen m. m. voorkomt, of wel van den wortel $l i$, die als variëteit van $l i h$ moet beschouwd worden en o. a. in 't Jav. liya zich vertoont. Wij komen later hierop terug. 
en mèmě: moeder; ngòpa en hòra: kind; uru en mòda: mond; gòko en kahitèla: maïs; bòro en gòsi: ei : gia en betèko: hand, arm; dòhu en bita: voet, been; ngèko en tāpàki, weg; diha en pamara: mes; tamo en ngogu: rijst; po kàtu en po sero: dak dekken, enz.; maar deze woorden zijn toch weinig in getal. - Andere woorden vervangt men door dezulke die er nauw in beteekenis aan verwant zijn, bv. po tàgi, gaan: pa tjobo, vertrekken; da mala, koud (op 't aanvoelen): da gòga, koud (het is -, men heeft het -); pa àso, roepen: po tigalo, aan- of toeroepen; o tahu, huis: o dadaru, afdakje, beschutting tegen regen of zon; $p a$ utu, plukken: pa towo, van den steel trekken; o tòko, kip: o namo, vogel; enz. - Voor sommige, makkt men een zelfstandig naamwoord van de werking, om het werktuig te noemen, bv.: o ngau, oor: o gogise, hoorder (gehoorwerktuig); o taïto, hakmes: o bobitogu, af hakker; o ngunu, neus: o sasangu, uitsnuiver; o silo, flambouw : o gagàku, beiichter; o paro, wind: 0 gigiwi, heenenweêrzwaaier; $o$ deru, praauw : o sosòra, overhaler, enz. - Voor algemeene benamingen, neemt men een deel in die benaming begrepen, bv. o igo, kokosnoot: o gopoa, jonge kokosnoot; o sahè, hoofd, en o hutu, haar: o bilèti, haarwrong, kondé; po mòku, pruimen: po dèna, areeknoten; 0 bole, banaan: o kasiala, zekere soort banaan; enz. - Voor nog andere ruilt men er een dat eene gelijkheid in beweging aangeeft, bv.: po òdo, eten: po magèsè, tot zich nemen; po hòru, roeien (scheppen): po wade, harken; po wusi, kammen: po rago, krabbelen; po uti, afdalen: po ma mòdota, zich afwerpen; po ruba, omvallen: po tigira lang uit liggen; po mä̈du, gaan slapen: po ma rubasa, gaan liggen ; enz. - Voor eenige neemt men een aan het voorwerp, dat men moet noemen, op te merken eigenaardigheid of eigenschap, bv. : o lupu, muis : o uru susuwo, spitsbek; o mnidjanga, hert: o bita-gìku, langbeen; o tewo, zeewater: 0 mimiri, het zilte; $o$ dalu, palmwijn : o gogiòpi, het verzuurde; enz. - Voor enkele ook worden woorden genomen uit het Ternataansch of uit een ander verwant dialekt, bv.: o gahu, kalk: o dafahe (Tern.); po dola, klimmen: po fere (Tern.); o diha, mes: odari (Tern.); o tamo, rijjst: o pinè (Tobè̀o); o tamo, rijst: o bira (Tern.); o tòko, kip: o tataleo (T'obèlo)."

"Uit het bovenstaande blijkt reeds dat één woord meer dan één vervanger voor het saäli kan hebben, en dit laat zich begrijpen, waar het dikwerf moet voorkomen, dat men zoo min het ware woord als het meest gebruikelijke sä̈li-woord mag bezigen. Het zou ite omslachitig wezen vele dezer saäli-woorden in de woordenlijst 5e Volgr. VIII. 
op te nemen; we zullen ons daar tot de meest gebruikelijke bepalen."

Tot zoover van Baarda, wien de dank toekomt van allen die belangstellen in de taal en volkenkunde van 't Maleisch-Polynesische ras, omdat de door hem vernelde feiten ons niet alleen met eene eigenaardigheid van de Galelareezen bekend maken, maar ook aanvullen wat wij van elders omtrent hetzelfde gebruik weten. Bij 't lezen van 't medegedeelde uittreksel zal het wel niemand ontgaan zijn dat het saäli der Galelareezen in verband staat met het eeuwenheugende gebruik dat onder de benaming pamali of tabu tot de kennis der Europeanen is doorgedrongen. Om dat gebruik in volle kracht te zien heerschen, moeten wij niet in de eerste plaats rondzien bij die volken der groote Oceanische familie welker maatschappelijke en godedienstige gebruiken diep ingrijpende veranderingen hebben ondergaan. Wel is waar zal men bij nauwlettend onderzoek vermoedelijk wel enkele herinneringen en $\min$ of meer verbasterde overblijfselen van 't oude gebruik aantreffen, maar om iets wat naar een vast stelsel lijkt te ontdekken moet men tot de onvervalschte of minst vervalschte stammen gaan. Beginnen wij met de Dajaks.

In het woordenboek van Hardeland onder 't woord pali treft men dezen volzin aan: pali manjewout aran indubapae tuntang kakarä paharie, d. i. het is pamali den naam te noemen van moeder en vader, alsook van alle verwanten." Op de taal moet zulk een verbod zekeren invloed oefenen, inzooverre men telkens tot omschrijving, verwisseling of verdraaiing van de te schuwen benaming de toevlucht moet nemen. Hoe de Dajak tabu-woorden vermijdt, ziet men uit Hardeland's spraakkunst, blz. 63. "Veel synoniemen zijn ook daardoor ontstaan dat menig woord voor zekere menschen pali, d. i. ongeoorloofd is uit te spreken. Het is pali den naam der ouders en grootouders, der ooms en tantes, alsook zijn eigen naam te noemen. Nu zijn zulke Nomina propria gewoonlijk ook namen van andere dingen, zoodat degenen, voor wie zulk een Nomen proprium pali geworden is, dan ook voor die andere dingen eene andere benaming moeten gebruiken, ten gevolge waarvan dikwijls voor de gansche familie en verder voor de geheele maagschap de oorspronkelijke benaming van zulk een ding in onbruik geraakt, of de nieuwe naam als synoniem naast den ouden in zwang komt. Men maakt zulke nieuwe woorden zelf, of verandert het oorspronkelijke woord eenigszins, of ook men ontleent dit nieuwe woord aan eene andere taal, vooral de basa Sangiang. Dus verandert men bijv. het woord nangka (een 
vrucht en mansnaam) in nangkis; - undang (garnaal en vrouwennaam) in undik; - voor pati (kist en mansnaam) bezigt men in zoo'n geval tabala, uit de basa Sangiang; - voor bulan (maan en vrouwennaam) panala (basa Sangiang); - voor kambang (bloem en vrouwennaam) lelek (bas. Sang.)

Wat de Dajak pali heet, noemt de Minahasser posan. In hoever de posan-voorschriften invloed op de taal kunnen oefenen, leeren wij uit de berichten van wijlen den zendeling P. N. Wilken. ${ }^{1}$ "De Alfoer, man of vrouw, mag nooit de namen der schoonouders noemen, omdat dit in hun oog gebrek aan achting verraadt, waardoor de overtreder met wonden en puisten, vooral aan den neus, gestraft wordt. Wordt de Inlander gevraagd, hoe deze of gene heet, dan antwoordt hij, wanneer bedoelde persoon gelijknaming is met een' van zijne schoonouders: "juist zooals mijn schoonvader", of "ik mag dien naam niet noemen", of hij geeft er eene omschrijving van, of noemt den naam half, als: voor $W$ enas zegt hij: $W e$, - voor Mainalo: Maina, - voor Waworuntu: Wawo. Wordt hij nog niet verstaan, dan voegt hij er nog eene lettergreep bij: Waworun, enz. Heeft hij bij vergissing den naam uitgesproken, dan spuwt hij, vooral wanneer de schoonvader of moeder reeds dood is, zeggende: "ik heb verkeerd gedaan." Bij herhaling van dit misdrijf wordt hij door zijne vrouw deswege streng berispt."

"Het niet mogen noemen van de namen der schoonouders gaat zoo ver, dat de Alfoer steeds voor slechts eenigszins gelijkluidende namen van levende of doode voorwerpen een ander verklarend woord gebruikt. Heet bijv. de schoonvader Wavoruntu, dan zal hij nooit zeggen: wawo (boven), maar wel natas (boven); heet hij Kalalo of Mainato, dan zal hij nooit zeggen: kawalo (paard), of pangalo (naam van eene soort gras), maar voor kavalo gebruiken: sasakejan (rijbeest), en voor pangalo: rukut kakannen ne sasakejan (eten voor rijbeesten). Is de naam van de schoonmoeder: Sijowan, dan zegt hị voor sijo (negen): Kehana (onpas); heet zij Ngisa, dan zegt hij voor marisa (spaansche peper): ngumetnget (heet, brandend, scherp), enz."

Het Dajaksche pali vinden wij op Madagaskar terug in den vorm fady. De invloed van dit gebruik op de taal wordt ons door Sibree ${ }^{2}$ aldus geschilderd: "Een ander geval van dialektverschil onder de Malagasische stammen is de vreemde, aan alle Polynesische talen

1 Mededeelingen van het Nederlandsch Zendelinggenootschap, VII, 133,

2 The great African island, pag. 150. 
gemeene gewoonte om woorden die als naam hunner hoofden voorkomen als fady of uit het gewoon gebruik gebannen te beschouwen. $\mathrm{Nu}$ bestaan in deze groote talengroep eigennamen voor een goed deel uit namen van gewone dingen - dieren, vogels, insecten, planten, boomen, enz. Maar als een van deze woorden bij geval den naam of een deel van den naam nitmaakt van het stamhoofd, dan wordt het heilig en mag niet langer als benaming van dat dier, enz. gebruikt worden. Dit laatste krijgt nu een anderen naam, dikwijls een beschrijvend epitheton of eene onschrijving. Zoo was wijlen Koningin Ràsohèrina vóór haar troonsbestijging in 1868 bekend onder den naam von Babodo, maar toen zij Koningin werd nam zij den naam aan van Ràsohèrina. Nu was sohèrina het woord voor den zijwormvlinder, doch zoodra het als naan der heerscheres werd aangenomen, kon het niet langer worden toegepast op het insect dat sedert zàna-dàndy, "kind der zij" genoemd is geworden. Zoo ook in 't geval van een hoofd in Westelijk Imérina die Andriamamba heette; mamba is een van de namen van den krokodil, maar de onderhoorigen mochten in 't gebied van hun hoofd het dier niet met dien naam noemen en droegen zorg altoos het andere woord voay te gebruiken. Het is alsof wij in Engeland alle woorden waarin de lettergrepen van de namen Victoria, William of George voorkwamen moesten vermijden en niet mochten zeggen "victory", "victim", "vixen", of "will", "willing", "wilful", of "geology", "geometry", "geography" enz. Wat een eindeloozen last zouden wij zulks vinden; toch is dit juist wat in de meest MaleischPolynesische landen en, eilanden plaats heeft. Het is niet moeielijk te zien welk een grooten invloed zulk een gebruik gehad moet hebben op de taal van verschillende gedeelten van Madagaskar en hoe veranderingen steeds voortgaan de tongvallen verder van elkander te scheiden."

Ook in Melanesië komen soortgelijke verbodsbepalingen omtrent het gebruik van zekere woorden voor. Zoo zegt Codrington ' gesproken te hebben over de regelen der etiquette die voorsehrijven bepaalde aanverwanten te mijden op de Bank's Eilanden: "Het vermijden van een naam toont een lageren graad van etrbied dan het vermijden van een persoon. Een man die met den vader zijner vrouw zit te praten zal diens naam niet noemen, veel minder den naam van de moeder zijner vrouw; hij zal ook niet den broeder。

1 Melanesians pag. 43. 
zijner vrouw noemen, wel haar zuster, want die bestaat hem niet. Eene vrouw zal haar mans vader niet noemen, hoewel zij hem niet vermijdt; zị zal in geen geval haar dochters man noemen. Twee personen wier kinderen met elkander getrouwd zijn, die gasala [Javaansch besan] zijn, zullen elkaar niet noemen. De terughoudendheid ten aanzien van den naam strekt zich uit tot het bezigen van het woord of van een gedeelte en van, in 't gewoon gesprek. Bij zekere gelegenheid sprak een man mij van zijn huis als een loots, en toen ik hem niet begreep, ging hij; het met zijn hand aanraken om te toonen wat hij bedoelde; toen dat nog niet hielp, keek hij rond om zeker te zijn dat er niemand in de buurt was en fluisterde, niet den nam van zijn zoons vrouw, maar het eerbiedige substituut voor haren naam, amen Mulegona, zij die met zijn zoon was, en wier naam Tawurima, Achterhuis was '. Om aan de moeielijkheid die door zalk eene beperking van den woordenschat ontstaat te gemoet te komen, mag men een woord oneigenlijk bezigen, zooals paito, loots, hut, voor ima, huis; of een mes kan men "snijder", en eenen boog "schieter" noemen; doch men heeft een aantal woorden in voorraad die opzettelijk voor dit doel gebruikt worden. Het bezigen hiervan instede van de gewone woorden heet un. - Dit vermijden van den persoon en den naam wordt door de inboorlingen zelven toegeschreven aan een gevoel van bedeesdheid en eerbied, een zekere inwendige siddering, welke, naar hun zeggen, hen ook belet hun eigen namen te noemen. Wanneer men een inboorling naar den naam van een ander vraagt, zal hij zich dikwerf tot een der omstanders wenden, die voor hem antwoordt, en de verklaring wordt gegeven in het eene woora qaliga. Men toont op Mota ook eerbied door een voornamwoond in den dualis te gebruiken wanneer men tot of van een enkel persoon spreekt; "Waar gaat gij beide heen?" vraagt men aan een qaliga, alsof beide, man en vrouw, tegenwoordig waren, $n$

Op de Nieuw-Hebriden is het gebruik nagenoeg hetzelfde.

Uit de aangehaalde feiten, die licht met nog andere zouden kumuen vermeerderd worden, mag men het besluit trekken dat de

1 Hierbij de noot: «Het woord amaia, met hem, wordt niet alleen voor den naam eener gade gebruikt, maar ook in plaats van "zijne gade; nang amaia va toen zeide zijne vrouw. In bovenbedoeld geval, bevat Tawurima, de naam der schoondochter, het woord ima, huis [Jav. umah, Mal. rumah.] De vader van Tawurima daarentegen zou niet het gewone woord voor gaan, mule [vgl. Jav. mulih] kunnen gebruiken, omdat het een deel is van haar mans naam, Mulegona.: 
instelling van het pamali, als ik het zoo noemen mag, althans in hoofdtrekken, alsook haar invloed op de taal, dagteekent uit het tijdperk der Maleisch-Polynesische taaleenheid. Het schijnt mij toe, dat ook de onderscheiding der zgn. taalsoorten in 't Javaansch niets anders is dan eene uitbreiding van het pamali. Het Javaansche gebruik toch komt daarop neêr, dat men sprekende over en tot meerderen, - of die men honoris causa als zoodanig behandelt zekere woorden vermijdt, en wel, deels door een synoniem te gebruiken (bijv. daměl voor gawe; dalèm, griya, voor omah); deels door het woord eenigszins te veranderen (bijv. kantun voor kari, dados voor dadi); deels door woorden aan een ander dialekt of een andere taal te ontleenen (bijv. sasi voor wulan). Al deze hulpmiddelen neemt, zooals wij gezien hebben, ook de Dajak te baat. Het verschil is dit, dat de Dajak alleen zoo te werk gaat wanneer een persoonlijke reden hem daartoe noopt, de Javaan echter niet als bijzonder persoon, maar als lid van een bepaalden stand in de maatschappij vermijdt aanstooc te geven. De onderscheiding der $\mathrm{zgn}$. taalsoorten is geenszins tot Java beperkt; in hoofdzaak hetzelfde verschijnsel treft men aan bij stammen die sedert onheugelijke tijden geen gemeenschap meer met de bewoners van Java kunnen gehad hebben; o. a. bij de Samoanen. "Er is een groot aantal woorden, zegt G. Pratt in zijn spraakkunst van het Samoa, "die men jegens hoofden en vreemden gebruikt, en het zou gelijk staan met eene beleediging indien men eenig ander woord bij 't aanspreken bezigde. Zulke woorden worden nooit door een hoofd gebruikt wanneer hij van zich zelf spreekt. Onder die woorden zijn er enkele die gebruikt worden naar gelang van den rang des persoons die men toespreekt; bijv. tausami, eten, - een eerbiedige uitdrukking tegen een dorpshoofd; taumafa - tegen een hooger hoofd; taute - tegen een opperhoofd." Aan deze korte opmerking voegt de uitgever der $2^{\mathrm{e}}$ uitgave der spraakkunst, S. J. Whitmee, nog nadere bijzonderheden toe: "Dit gebruik van bijzondere woorden bij 't aanspreken van bijzondere pereonen is een belangrijk verschijnsel van de Samoaansche taal. Een blik in het woordenboek zal toonen hoe menig woord eigenaardig tegen een hoofd gebruikt wordt. Bijna ieder lid van zijn lichaam heeft een naam die verschilt van dien welke voor een gewoon mensch geldt Zijne gewaarwordingen, zijne handelingen en zijne bezittingen hebben afwijkende namen. In veel gevallen wordt de gewone benaming van een ding verwisseld met een andere, wanneer daarvan in zijne tegenwoordigheid gesproken wordt. Som- 
wijlen wordt de graad van iemands waardigheid door 't gebezigde woord aangeduid, zooals in de woorden voor eten boven, vermeld. Een ander voorbeeld leveren de volgende woorden voor komen. Sau zegt men tot een gewoon mensch; maliu mai is een eerbiedige uitdrukking een trapje hooger; susu mai bezigt men alleen voor hoogere hoofden; en afio mai eigenlijk alleen tegen hoofden van den hoogsten rang."

Dit verplicht gebruik van Krama-inggilwoorden vinden wịj ook terug in 't uiterste westen van het taalgebied, op Madagaskar. "De heiligheid die de Hova's aan de koningsnamen hechten", zegt Sibree (p. 169) "wordt na den dood des heerschers uitgestrekt tot alles wat op hun graven en lijkplechtigheden betrekking heeft. Zoo zeggen zij niet van een koning dat hij gestorven is, maar dat hij zich verwijderd heeft, niamboho, letterlijk "heeft den rug toegekeerd" aan zijne onderdanen, of is naar huis gekeerd om te gaan liggen, nodimandry. Zijn lijk wordt niet faty [vgl. Jav. pati] genoemd, maar ny masina "het gewijde"; en het wordt niet "begraven" (alevina), maar "verborgen" (afenina); en zijn graf is niet een fasana, maar trano masina, het gewijde huis, waarin de zilveren lijkkist, lakambola, "zilveren boot" verborgen wordt. Alles kortom draagt eene bijzondere benaming verschillende van die welke aan dezelfde zaak in betrekking tot het volk in 't algemeen toekomt."

$\mathrm{Na}$ een ietwat langen, doch noodigen omweg komen wij nu terug op het Galelasche saäli. Reeds het woord op zich zelf herinnert ons aan Dajaksch pali, Malagasi fady, Maleisch pamali, Bugineesch pemali, alsook aan Makassaarsch kasipali. Pali enz. gaat in laatste instantie terug op een wortel $l i$, waarvan lih, lik, lin, leh als bijvormen, en lah als wortelvariant te beschouwen zijn. Vgl. bijv. Jav. wali, alih, malih, ulih, walik, seleh, salah, sulih, silih en de overeenkomstige vormen in de verwante talen. In $l i$ enz. ligt in 't algemeen het begrip van keeren, wenden; in samensteling met het reflexiefwederkeerige $s i, s a, s u$ gat het begrip over in de beteekenis van wisselen, verwisselen , opzijzetten , altereeren ${ }^{\mathbf{1}}$; uit "opzijzetten " ontwikkelt zich verder het begrip van "afzonderen, uitzonderen", welke beteekenis wij o. a. in het Tagalog pasubali, uitzonderen, aantreffen. Welke zin ligt nu in pali? Is het "wat verkeerd is?" en dan zou het een synoniem zijn van het wortelverwante salah .- , of "wat veranderd

1 Ook met andere voorvoegsels kan $l i$ soortgelijke begrippen uitdrukken, o. a. in Oudjav. wĕli, Mal. b̧̋li, Fidji voli, koopen en ruilen; Jav. pilih, enz. kiezen. 
wordt" , of "wat op zij gezet, afgekeurd wordt" ? Voorshands, geloof $\mathrm{ik}$, mag men aannemen dat al die beteekenissen in het woord opgesloten liggen. Het Galelasche saäli is ongetwijfeld eene ontwikkeling van denzelfden wortel $l i$ of $l i h$, die in alle verwante talen in een grooter of kleiner aantal afleidingen voorkomt, en $s a$ idenitisch of althans nauw verwant met Jav. enz. $s a$, wortelvariant: $s i, s u$, sang, san. Of nu saäli eenvoudig z. v. a. Jav. silih is, dan wel of een andere beteekenis, als die van pali, er mede in opgesloten ligt, kan vooralsnog niet uitgemakt worden. Opmerkelijk is het dat het bekende woord tabu, hetwelk in beteekenis, doch niet in wortel overeenkomt met pali, ook de beteekenis vertoont in het Fidji van "uitgezonderd, uitgelezen, uitnémend", evenals Tagaleg pasubali: uitzonderen. Het Tagalog pali is, "keer in een reizang;" hierin komt de oorspronkelijke beteekenis van $l i$, enz. duidelijk uit.

Het zooeven vermelde qaliga van de Banks-eilanden zou in 't Jav. letterlijk overgebracht, luiden walikan. 